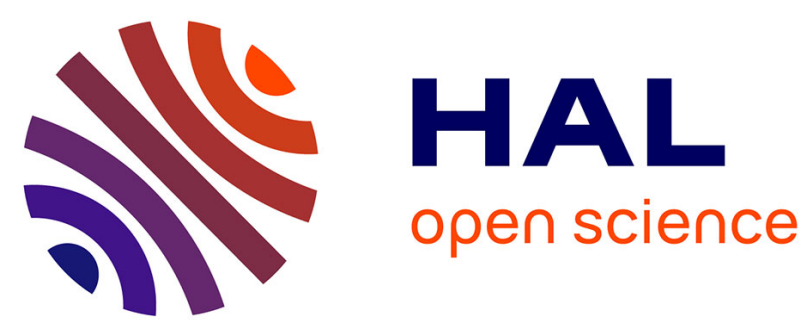

\title{
Providing Cheap Land for Social Housing: Breaching the State Aid Regulations of the Single European Market?
}

Tuna Taşan-Kok, Daniëlle A. Groetelaers, Marietta E.A. Haffner, Harry M.H. van Der Heijden, Willem K. Korthals Altes

\section{- To cite this version:}

Tuna Taşan-Kok, Daniëlle A. Groetelaers, Marietta E.A. Haffner, Harry M.H. van Der Heijden, Willem K. Korthals Altes. Providing Cheap Land for Social Housing: Breaching the State Aid Regulations of the Single European Market?. Regional Studies, 2011, pp.1. 10.1080/00343404.2011.581654 . hal00724060

\section{HAL Id: hal-00724060 \\ https://hal.science/hal-00724060}

Submitted on 17 Aug 2012

HAL is a multi-disciplinary open access archive for the deposit and dissemination of scientific research documents, whether they are published or not. The documents may come from teaching and research institutions in France or abroad, or from public or private research centers.
L'archive ouverte pluridisciplinaire HAL, est destinée au dépôt et à la diffusion de documents scientifiques de niveau recherche, publiés ou non, émanant des établissements d'enseignement et de recherche français ou étrangers, des laboratoires publics ou privés. 


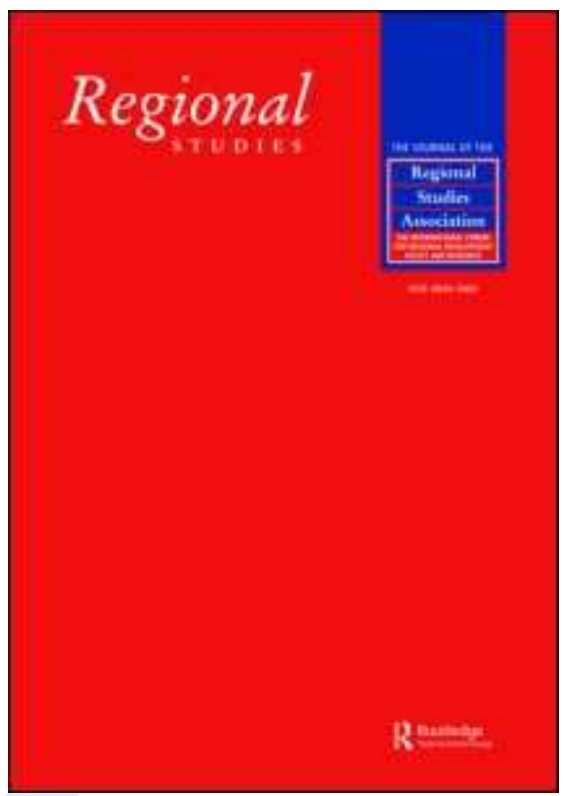

\section{Providing Cheap Land for Social Housing: Breaching the State Aid Regulations of the Single European Market?}

\begin{tabular}{|r|l|}
\hline Journal: & Regional Studies \\
\hline Manuscript ID: & CRES-2010-0188.R2 \\
\hline Manuscript Type: & Policy Debates \\
\hline JEL codes: & $\begin{array}{l}\text { F15 - Economic Integration < F1 - Trade < F - International } \\
\text { Economics, H79 - Other < H7 - State and Local } \\
\text { Government|Intergovernmental Relations < H - Public Economics, } \\
\text { K29 - Other < K2 - Regulation and Business Law < K - Law and } \\
\text { Economics, R31 - Housing Supply and Markets < R3 - Production } \\
\text { Analysis and Firm Location < R - Urban, Rural, and Regional } \\
\text { Economics }\end{array}$ \\
\hline Keywords: & $\begin{array}{l}\text { state aid, land price, social housing, Single European Market, The } \\
\text { Netherlands }\end{array}$ \\
\hline
\end{tabular}

\section{SCHOLARONE \\ Manuscripts}




\title{
Providing Cheap Land for Social Housing \\ Breaching the state-aid regulations of the Single European Market?
}

\author{
Tuna Tasan-Kok*+ \\ Danielle A. Groetelaers* \\ Marietta E.A. Haffner* \\ Harry M.H. van der Heijden* \\ Willem K. Korthals Altes* ${ }^{\mathrm{x}}$ \\ *Delft University of Technology, OTB Research Institute for the Built Environment, \\ Jaffalaan 9, 2628 BX Delft, The Netherlands. E-mail: m.t.tasan-kok@tudelft.nl, \\ d.a.groetelaers@tudelft.nl, m.e.a.haffner@tudelft.nl, h.m.h.vanderheijden@tudelft.nl, \\ w.k.korthalsaltes@tudelft.nl
}

${ }^{+}$METU Department of City and Regional Planning, Faculty of Architecture 06531, ODTU Ankara, Turkey. E-mail: tasankok@metu.edu.tr

${ }^{\mathrm{x}}$ corresponding author

(Received June 2010: in revised form April 2011) 


\begin{abstract}
EU member states are not permitted to provide aid which will distort competition by favouring certain undertakings or the production of certain goods which may then undermine trading in the European market. This prohibition also affects government authorities that are willing to provide cheap land for social and affordable housing. This paper reviews the ways in which land is provided for social housing in the Netherlands and explores possibilities for re-shaping current practices to make them compatible with the regime of the Single European Market.
\end{abstract}

\author{
Key words: state aid, social housing, land price \\ JEL-codes F15, H79, K29, R31
}

\title{
1. Introduction
}

The formation of the Single European Market was an institution-building project formulated in the 1980s to boost the European agenda (FLIGSTEIN and MARA-DRITA, 1996). It functioned as a response to the challenges of globalisation and reflected the rise of neo-liberal free market ideas (SMALLBONE et al., 1999). The reforms aimed to promote European-wide economies of scale by eliminating non-tariff trade barriers such as differences in regulation, taxation and health and safety standards (FLIGSTEIN and MARA-DRITA, 1996). State aid for specific undertakings, although already addressed in the Treaty of Rome (EEC, 1957), may be considered a non-tariff trade barrier insofar as it may distort the level playing field which the European institution builders aimed to 
provide. The long history of the attempt to control state aid, however, does not imply that all existing practices of state aid be structured by the principles of the Single European Market. Kroes, the former European Commissioner for competition policy, indicated that although the control of state aid 'keeps the market alive', these controls 'are harder to exercise than it may appear' (KROES, 2009). Europeanisation is a lengthy and disjointed process of adjustment (KORTHALS ALTES, 2010).

The European Commission (EC) is responsible for monitoring the European market to ensure that competition between undertakings is free and fair. This is done, for example, by preventing collusion between suppliers and by ensuring that competing contractors are admitted into tendering processes (KORTHALS ALTES, 2006; BENNETT, 2006; KORTHALS ALTES and TAŞAN-KOK, 2010). In July 2005 the Commission sent the Dutch government a letter concerning competition and the non-admissibility of certain forms of state aid for housing associations. The forms of state aid listed in the letter were: loan guarantees by the Dutch Social Housing Guarantee Fund (Waarborgfonds Sociale Woningbouw or WSW), systematic aid to the sector by the Central Social Housing Fund (Centraal Fonds voor de Volkshuisvesting or CFV), exemption from corporation tax, and cheap loans through the Dutch Municipalities Bank (Bank Nederlandse Gemeenten or BNG) and the Dutch District Water Board Bank (Nederlandse Waterschapsbank or NWB) (EC, 2009b).

The letter made no mention of the fact that many Dutch municipalities make building land available to housing associations at lower prices than those paid by private 
developers (GRUIS and PRIEMUS, 2008). Since then, the Association of Institutional Property Investors in the Netherlands (Vereniging van Institutionele Beleggers in Vastgoed, Nederland or IVBN) has complained to the Commission about the way in which Dutch local government favours housing associations. In this complaint, the provision of cheap building land is explicitly described as a form of state aid that is unrecognised by the Commission (PRIEMUS, 2008).

This contribution explores the relationship between the provision of cheap building land for housing associations and the European legislation on state aid by concentrating first on the situation in the Netherlands and then relating it to other European countries. Across Europe, social housing is supplied by a variety of landlords such as municipalities, non-governmental organisations, housing associations and/or private housing companies (WHITEHEAD and SCANLON, 2007). Resource allocation mechanisms under various sets of relationships between the state and the market play an important role in the provision of social housing (OXLEY, 1995). Within this framework, this contribution questions how European competition policy may influence the social housing sector in terms of the provision of affordable land for the builders of social housing. This implies that the contribution does not generally address the question of the effectiveness of state aid or the effects of reducing state aid in relation to the provision of land for social housing.

The following questions will be discussed in this contribution: Does the municipal practice of setting low land prices for housing associations constitute state aid under 
European law? If so, under what conditions is this form of state aid admissible? Are the public land-pricing policies for social housing across Europe in danger of being tagged as inadmissible state aid?

This contribution will begin by clarifying the European definition of state aid and its relationship to organisations that offer services of general economic interest (SGEI). It will then examine the matter of land transactions and financial compensation, represented here as land purchases by Dutch social housing providers, and review two options for the supply of land for social housing in relation to state aid legislation (which includes the recent agreement between the Commission and the Dutch government). Following this, it will describe land provision practices in other European countries and discuss whether lower land prices could be inadmissible under the legislation on state aid. It concludes with a discussion that includes implications of European state aid regulations, such as, on social inclusion policies and other spatial effects.

\section{Methods and data}

We derived basic information concerning land provision practices across Europe from the study by Needham and De Kam (NEEDHAM and DE KAM, 2000) (see Table in Appendix 1). We updated this information by adding data from the European Federation of Public, Cooperative and Social Housing (CECODHAS, 2010), which records statistics concerning social housing across Europe, and by conducting an online survey to determine the current land-price situation in various European countries. The online survey consisted of six questions about the provision of land for social housing. Thirteen 
academic experts responded to the survey (from eleven European countries: Belgium, Denmark, Finland, France, Hungary, Ireland, Italy, Poland, Slovenia, Sweden and the UK), all specialists in social housing, housing and urban studies (see Appendix 2 for the survey questions).

\title{
2. State aid and services of general economic interest
}

State aid is one of the major non-tariff barriers standing in the way of the establishment of a single market in the European Union. The general principle is that state aid is not permitted and that unjustified state aid must be repaid. Since 1957, the European Treaties have banned selective state aid which distorts competition:

\begin{abstract}
Save as otherwise provided in the Treaties, any aid granted by a Member State or through State resources in any form whatsoever which distorts or threatens to distort competition by favouring certain undertakings or the production of certain goods shall, in so far as it affects trade between Member States, be incompatible with the common market. (EU, 2010, article 107 paragraph 1; see also EEC, 1957, article 92, paragraph 1)
\end{abstract}

\begin{abstract}
As this article is more than 50 years old, it has been interpreted through many judgments by the European Court of Justice (ECJ), which generally indicate that it is correct to use a very broad interpretation of its concepts (SMITH, 1998); for example, the concept of
\end{abstract}


state resources includes tax abatements for specific areas (ECJ, 2006). In assessing whether state aid potentially distorts competition, the principle as such has become more dominant in comparison to the fact whether trade within the EU actually is being hampered. Even though the broad interpretation of distortive state aid has been confirmed, the Commission may allow certain exceptions, for example for aid in areas that are addressed by cohesion policies, aid for research and development or aid for small and medium-sized enterprises (SMEs). In these cases, state aid cannot be provided without the Commission's prior consent, which is sometimes given through block exemption regulations (CEC, 2008b).

The ECJ defines an 'undertaking' as 'every entity engaged in an economic activity, regardless of its legal status and the way in which it is financed' (ECJ, 1991, paragraph 21). Hence, an undertaking is understood as any legal entity in private and public law. 'Economic activity' is taken to mean 'any activity consisting in offering goods and services on a given market' (ECJ, 1987, paragraph 7). To determine whether or not an entity qualifies as an undertaking, it is necessary to consider the nature of its tasks and activities and the way in which these may have been incorporated in legislation, and to determine the presence or absence of a competitive situation; for example, a non-profit organisation (such as a foundation) which engages in economic activities in competition with other organisations is an undertaking within the meaning of the European Treaties. 
These criteria make it clear that when a municipality supplies land to a housing association it could be making a provision to an undertaking. Such an act could therefore fall within the domain of state aid.

The Commission (CEC, 1997) has issued a 'communication' which sets out the conditions under which the sale of land and buildings by public bodies does not constitute state aid. The transaction must be concluded at a price that complies with the market value, calculated on the basis of normal economic activity. The Commission (CEC, 1997) identifies two main principles: sale via an 'unconditional bidding procedure', which is an open, non-discriminatory and unconditional contracting procedure, and sale without an unconditional bidding procedure (see Figure 1). Under the first principle, the bidding procedure ensures that the sale is transacted at the market price; under the second, a valuation is required in order to arrive at a market price. The key criterion here is therefore the market price.

The sale of land through an open, unconditional and sufficiently public bidding procedure does not count as an instance of state aid because such a sale assumes the character of an auction in which the best or only bid is, by definition, the market price. In the absence of an unconditional bidding procedure, there could still be a market price if the land has been valued by an independent expert. The actual price paid may then deviate by $5 \%$ from this valuation. If the land in question cannot be sold within a reasonable period of time, then a new value may be set. The authority must ensure that the valuation is properly carried out (CEC, 1999; 2001). The Commission '... considers that the "market 
price" is not the price such a commercial developer would be willing to pay, but rather the price for which such a commercial developer would be willing to sell the same plot to a buyer ...' (CEC, 2001, 52). Thus, even if the land development plan states that the area is agricultural land, the proposed urban use of the land must be taken into account.

The Commission communication (CEC, 1997) appeared to be primarily directed at the sale of government property and not at the issue of development land. For example, the valuation price may not be lower than its original purchase price if the transaction takes place within three years. However, in land supply, the selling price by definition differs from the purchase price because works have been carried out in the meantime (to prepare the land for development and housing). Moreover, in a transaction involving a government building for example, the building is regarded as an end product, whereas development land is regarded as an 'intermediary product' whose value is codetermined by the end product (housing, offices, etc.) (NEEDHAM, 1992; MORI, 1998; VAN DIJK et al., 2007). If local authorities fail to follow an unconditional bidding procedure or to order a valuation and sell land below the market price to a provider of social housing, then state aid may be implied (see also Figure 1).

\title{
[[FIGURE 1 ABOUT HERE]]
}

\begin{abstract}
It may be permissible to sell low-priced land to housing associations that develop social housing if the price paid is regarded as compensation for providing services of general economic interest (SGEI). The concept of SGEI goes back to the Treaty of Rome, which
\end{abstract}


was ratified by the six founding members of the European Economic Community (EEC, 1957) and is based on the idea that the delivery of public services or, better stated, the French doctrine of 'le service publique', which allows the state to decide that certain products and services fall under public services (BRUHNS, 2001), is an integral part of national identity which must not be compromised by European cooperation.

Undertakings entrusted with the operation of services of general economic interest or having the character of a revenue-producing monopoly shall be subject to the rules contained in this Treaty, in particular to the rules on competition, in so far as the application of such rules does not obstruct the performance, in law or in fact, of the particular tasks assigned to them. The development of trade must not be affected to such an extent as would be contrary to the interests of the Community. (EEC, 1957, article 90, paragraph 2; EU, 2010, article 106, paragraph 2)

It is this term that shapes the debate on the provision of public services (PRIEMUS, 2006). The Treaty of Rome does not use the term 'public services', as the member states may decide for themselves whether SGEI are delivered publicly or privately (BRUHNS, 2001). Accordingly, the services may be provided by hybrid organisations such as housing associations. Even though the term SGEI was woven into the concept of 'territorial cohesion' in the subsequent Treaty of Amsterdam (BRUHNS, 2001; FALUDI, 2006), it is not defined in the formal texts or in secondary legislation (CEC, 2004). Moreover, the delivery of public services differs between and sometimes within member states (ANDREWS and MARTIN, 2010). The Commission defines SGEI as: 
... services of an economic nature which the Member States or the Community subject to specific public service obligations by virtue of a general interest criterion. The concept of services of general economic interest thus covers in particular certain services provided by the big network industries such as transport, postal services, energy and communications. However, the term extends to any other economic activity subject to public service obligations. (CEC, 2004, 22)

\begin{abstract}
The fact that SGEI are of specific interest to the Commission comes as no surprise, as it is the economic aspects of the services that would be subject to market rules (CEC, 2005b). If financial support is extended to undertakings that provide SGEI, then what might otherwise be classified as state aid falls into a different category (BRUHNS, 2001; CEC, 2005b). In such cases it is permissible to provide financial compensation in recognition of the fulfilment of a public service imposed by the state. The Altmark Judgment by the European Court of Justice (ECJ, 2003) sets out the criteria for defining state aid as compensation for SGEI (see also BENNETT, 2006; GRUIS and PRIEMUS, 2008; LOUIS and VALLERY, 2004; ELSINGA et al., 2008):
\end{abstract}

1. The undertaking that receives the support is actually required to discharge clearly defined public service obligations.

2. The parameters for calculating the compensation must be established beforehand in an objective and transparent manner. 
3. The compensation does not exceed what is necessary to cover all or part of the costs incurred in discharging the public service obligations, taking into account the relevant receipts and a reasonable profit.

4. In situations where the undertaking which is to discharge public service obligations is not chosen in a public procurement procedure, the level of required compensation is determined on the basis of an analysis of the costs which a typical well-run undertaking - with adequate means to meet the necessary public service requirements - would have incurred in discharging those obligations, taking into account the relevant receipts and a reasonable profit.

If these four criteria are met, the set price is deemed a market price, which includes compensation for the undertaking that provides the SGEI. There is therefore no question of state aid. If the four criteria are not met, or if there are doubts, the payment must be declared as state aid and may be confirmed as such. There is, however, a very thin line between state aid and allowable compensation for providing public services (KORTHALS ALTES, 2006). The determination of an SGEI, that is, the determination of the obligations of the service provider, is a task for the public authorities of a member state (CEC, 2004). Based on the Altmark Judgment, the Commission (CEC, 2005b) states that although national legislation has scope for discretion, further criteria must be specified for the recognition of an SGEI. 


\section{Two options for reshaping the Dutch practice of providing cheap land for housing associations}

Municipalities play a large role in the servicing of land in the Netherlands. Even if potential building land has been acquired by development companies, they usually transfer this land to local authorities or public-private corporations that provide infrastructure and sell the serviced plots to developers, housing associations and end users (GROETELAERS and KORTHALS ALTES, 2004). The price of land earmarked for private housing development is determined either by 'residual calculation' or a variant thereof, or it is codetermined by public and private parties. Residual calculation (Figure 2) sets the price of land through the net present value of all future proceeds and costs, including construction costs, related to the property. The maximum land price is the property price less the construction costs and additional costs, including a reasonable profit margin. This entails that the seller earns the windfall profits. Many municipalities use this method as a framework for their calculations. As there may be large discrepancies in the estimates of future costs, revenues and the discount rate, residual calculation does not preclude negotiations about pricing. Especially in cases where development is uncertain, this may result in the division of windfall gains across the parties. Local authorities also use derivative forms of residual calculation such as the land-quota method. This method calculates the land price as a percentage of the property price. Using a residual calculation, these percentages are fixed in advance based on the type of dwelling, while actual land prices will fluctuate with the property market. 
[FIGURE 2 ABOUT HERE]

These processes do not always lead to market pricing as envisaged by the Commission (CEC, 1997). A bidding procedure is used occasionally (VAN DER HEIJDEN et al., 2006), but in the Netherlands, independent valuation is almost never employed in the provision of land.

Dutch municipalities generally sell land destined for social housing at a lower price than land destined for market-sector housing. Most municipalities apply a fixed land price for social housing and other social real estate projects because the homes are built to address the needs of a specific target group. However, it is not always clear how these land prices are determined: 'For social housing in particular, many municipalities still use the old Decree on Housing Related Subsidies (Besluit Woninggebonden Subsidies or BWS), which applies a fixed land price when calculating the size of the subsidy' (ECORYSVASTGOED, 2006, 21: translation by authors). The use of a different price-setting method does not necessarily imply state aid, given that a housing association is a special type of undertaking which delivers an SGEI.

The question becomes whether the housing associations and the state aid or compensation they receive do indeed meet the Altmark criteria. Two lines of argument may be followed in the case of a clearly described public service obligation. The first is that housing associations meet this criterion because they perform a public duty under the Dutch Housing Act (Woningwet) and the regulatory legislation on the Dutch social rental sector 
(Besluit Beheer Sociale Huursector, or BBSH). The second is that the public service obligation is clearly described for each land transaction involving a housing association.

It must be acknowledged that the current definition of public duty in the BBSH - the preferential provision of appropriate housing for house-seekers with lower incomes (Section $13, \mathrm{BBSH})$ - is not exactly watertight. In principle it is possible to define a public duty, including a reporting and accountability duty, in a manner that meets the Altmark criteria, but it will take time before this becomes available. Hence, for the time being at least, the second line of argument - the definition of public service obligation for each transaction - is more relevant. No attempts to use predetermined parameters to calculate the compensation for housing associations in terms of cheap building land have thus far been observed in the Netherlands. In the rest of this section we will therefore concentrate on the way public service obligation can be described and maximum compensation calculated on the basis of each transaction.

Under the Altmark Judgment the maximum compensation is the difference between the price of the land if designated for private development (on the basis of public procurement, or for an average undertaking) and the price of the land if designated for SGEI. In order to establish the market price of this land, a bidder (in a public procurement process) or a valuer has to assess the housing that is to be built there. If we take this housing as our starting point, the difference between the market price and the SGEI price (for comparable housing) is expressed by the difference in value between a private housing development and a development with SGEI status. 
As dwellings with SGEI status are managed as rental dwellings over a longer period of time, 'replacement values' have to be applied to calculate the value and hence the maximum compensation. What counts then is the difference in net current market value between a private dwelling and an identical rental dwelling with SGEI status. This difference then provides the leeway for lowering the price of the land (land price discount) to compensate for the delivery of an SGEI (social housing). The next logical question is: How should these two replacement values be calculated?

The market replacement value of a privately owned dwelling can be equated with its market value; since if the market is doing a proper job, the replacement value and the market value will be one and the same.

The calculations to determine the replacement value of a dwelling with SGEI status must take into account the anticipated operational receipts (income from rent and the residual value of the dwelling after a given operational period) together with the operational expenses (management and maintenance costs, municipal property taxes, homeowners' insurance, etc.). Because of its below-market rent, the replacement value of an SGEI dwelling will be lower than that of a private dwelling. This difference determines the range for the discount on the market rate for development sites.

We can therefore conclude that if the calculated replacement value of an SGEI dwelling plus the discount on the commercial price of the land is lower than or equal to the market 
value of an identical private dwelling, there is no question of state aid. If the calculated replacement value of the SGEI dwelling plus this discount is higher than the market value of the private dwelling, then state aid comes into play.

\begin{abstract}
Based on the Altmark Judgment (ECJ, 2003), any financial compensation has to be calculated objectively, transparently and explicitly before the land transfer takes place. In order to meet this condition, maximum compensation can be determined on the basis of standardised guidelines for determining the replacement value of the proposed housing development. There are two crucial issues here: the proposed rental income and the period that the social rental income is received. These two issues should therefore be explicitly considered when describing the public service obligation attached to any provision of land.
\end{abstract}

As far as the rental income is concerned, it is clear that when a municipality sells land to a housing association for the purposes of social housing at less than the market price, it is, in effect, compensating the housing association for below-market rents and thus lower replacement values. In order to determine the maximum compensation before the land transfer takes place, it is therefore vital to know and take into account future rental levels. In the transposing of these rents to a present value, it is important to note, as the Commission (EC, 2009b) is aware, that the Dutch housing associations can use a low discount rate as their loans are guaranteed by the state through the Dutch Social Housing Guarantee Fund and consequently have an AAA rating. The discount rate used should carefully address state aid questions (such as the question whether the loan is only taken 
out for the building or for the land as well). Within this framework, a municipality that is engaging in a land transaction can explicitly state the maximum rents which the housing association may charge.

The period of social rental housing management is also vital to the determination of the replacement value. In the Netherlands, the replacement value of social rental housing is usually calculated on the basis of continued management as social housing over an expected life span of 50 years. Since a replacement value based on below-market rent is lower than the market value of private housing, it is only to be expected that an early sale of the property on the open market would lead to a higher replacement value and therefore to a lower maximum level of allowable compensation in the form of the discount on sites. It is therefore essential, prior to any land transaction, to make absolutely clear the length of time that the development will be managed as social rental housing. This issue can be approached in a number of ways.

One option is to limit the envisaged period of social rental housing to, for example, 20 years, and to calculate the maximum compensation accordingly. After 20 years the housing association would then be free to sell the dwellings on the open market. Another option is to free up land for social housing development under a long-term lease. This would enable municipalities to place constraints on the investment in any real estate built on the land. The market value of the land will thus vary according to the obligations set, such as the rent level, the length of the management period and the discount rate (See also ECORYS-KOLPRON, 2002; BUITELAAR et al., 2004). 
In the meantime the Dutch situation has moved on. In December 2009, the Commission issued a press release stating that an agreement had been reached with the Dutch government on bringing the social housing system into line with state aid regulations: 'In order to prevent situations where publicly supported housing is allocated to persons that are not in need of social housing, the Dutch authorities will adopt a new procedure ensuring that the allocation of dwellings is conducted in a transparent and objective manner' (EC, 2009a, see also 2009a). One can interpret this agreement that has been enforced as of 1 January 2011 as a clarification in terms of the general rules of what constitutes public duty. If this is considered 'enough' clarification, this would take away the need of the type of calculation as was elaborated above in the transaction approach.

\section{How land is provided for social housing in other EU countries}

According to Needham and De Kam (2000), social housing sectors are characterised primarily by a scarcity of land, especially in the inner city, and face subsequent high prices. There are some exceptions, such as Belgium (both Flanders and Wallonia), Luxembourg and Sweden, who reportedly had sufficient land reserves for social housing at the beginning of the 2000s. However, the situation in these countries changed during the second half of the decade. In Luxembourg land prices in some areas rose by more than $300 \%$ within ten years and exhausted the land reserves for social housing (CECODHAS, 2010, view/86/128). In fact, the main challenges for housing policy in 
Luxembourg - according to CECODHAS - is how to stop the rise in the price of development land and how to improve the supply of affordable rental and owner-occupier housing. In Belgium the rapid increase in the square-metre price of new building plots also pushed up the costs of constructing social housing, especially in Flanders (CECODHAS, 2010, view/76/118) and inevitably impacted on the reserves for social housing. Similarly, in Sweden, although municipalities were reported to have large land reserves for social housing at end of the 1990s, the tight land market has made it difficult to acquire land in Stockholm. Moreover, until the credit crunch struck, five to seven years of strong economic growth was forecast for Sweden and an increase in the construction of housing was expected. This situation was then expected to lead to higher land prices and higher construction costs in the social housing sector (CECODHAS, 2010, view/79/121).

Most of the other EU countries examined in this study (Austria, Denmark, France, Italy, Norway, Portugal, Spain and the UK) report a shortage of land for social housing, high land prices and difficulties in acquiring land for social housing. In Spain, for example, the impact of higher land prices and construction costs on the cooperative sector has inhibited the construction of affordable homes. Production did, however, increase towards the mid-2000s (CECODHAS, 2010, view/80/122).

As social housing clients cannot afford market rents, the builders of social housing are in a weaker position than other market players when attempting to acquire land on the market. This is why social housing providers usually attempt to acquire land at its 
minimum value (NEEDHAM and DE KAM, 2004). In this they are often supported by the public sector (NEEDHAM and DE KAM, 2000). Social housing providers prefer to build dwellings on serviced sites, that is, sites that are ready for housing construction, because the infrastructure is already in place (DE KAM et al., 2008). Land can be serviced by the state, the private sector (commercial developers, community land trusts or housing cooperatives) or by the social housing providers (public or private) themselves (DE KAM et al., 2008).

\begin{abstract}
As was argued above, EU regulations may prove burdensome to the social housing sector in the Netherlands when it comes to the provision of cheap land for social housing. Then the interesting question is: could this also apply to other countries? Yes, as there are many different ways in which the public sector (local or central government) can support social housing (UNECE, 2006; NEEDHAM and DE KAM, 2000) that may cause infringements with respect to state aid. It may occur if authorities:
\end{abstract}

1. Reserve land solely for the development of social housing and prevent competition

2. Grant subsidies to support the acquisition of land or the reduction of construction costs

3. Provide financial assistance for home-buyers or tenants

4. Reduce land prices by imposing planning controls 
It is not the individual method used that determines whether state aid is an issue, rather state aid becomes a matter of utmost concern if the combination of these methods results in a situation in which state resources favour a selective group of undertakings. Providing land at below-market prices, especially through subsidies to the producers or suppliers of land and housing, may further complicate such a context.

\section{Lowering the price of land for social housing using different European approaches}

In most EU countries, land has traditionally been offered to social housing providers at below the market price (see Appendix 1). In some countries, such as Austria, Belgium, Germany, Italy and Luxembourg, builders of social housing are favoured by prices below the market level. In the Flanders region of Belgium, the Ministry of Finance assesses the price of land for social housing on the basis of the designation of the land use and value of the property in the district plan. In this way, the district plan defines the basis of the market value. In Wallonia a special committee (Comité d'Acquisition) of the Ministry of Finance estimates the value of the land for social housing development based on a market evaluation, that is, the market value of the land. If the land has still to be serviced, most of the costs are subsidised by the regional government and all other servicing costs are paid by the housing association with a view to rental housing and future sales (NEEDHAM and DE KAM, 2000).

\footnotetext{
In Italy, land can be reserved for social housing in special areas called PEEP (Piano di edlizia economia e populare - the low-cost popular housing plan). The municipality can use compulsory purchase orders to acquire land for social housing, which must not
} 
exceed $50 \%$ of the market value (NEEDHAM and DE KAM, 2000). France can also be added to this group because some French municipalities acquire land which they then offer to social housing providers, sometimes at below-market prices (even token prices), frequently transferring not the freehold title but a ground lease. Some municipalities pay part of the land-servicing costs. Even if the price of land for a particular social housing project exceeds the valuation (verified by the public valuer), the sale may still go ahead (NEEDHAM and DE KAM, 2000). In Germany, the price of land for social housing is a matter of negotiation and social housing providers have no rights to land at reduced prices. Municipalities can sell sites either at a lower price or at a fixed price agreed to by the city council.

In other countries, prices are reduced through loans or subsidies. In Norway, social housing providers are given loans and grants from the State Housing Bank but only if the value of the land is below a certain level. In the UK, the price of land as such does not have to meet certain conditions but regulations are in place to secure affordable housing through the planning system. Planning obligations under Section 106 of the Town and Country Planning Act are well known in the field. They allow local authorities to enter into a legally binding agreement with developers who contribute to the provision of new infrastructure and other public assets in return for planning permission. The total value of all obligations agreed in 2007 and 2008 in England amounted to $£ 4.9$ bn, of which $£ 2.6$ bn was for affordable housing (CROOK et al., 2010). In 2005, the British government issued local authorities revised guidelines to bring about changes that would restrict planning obligations (OXLEY, 2008). In the mid-2000s, the Community Infrastructure 
Levy was proposed as a standard charge on new development to support infrastructure delivery, which includes affordable housing (OXLEY, 2008). The effects of this new tax on the price of land for social housing are yet to emerge.

In the Netherlands, as explained in detail above, most municipalities apply a fixed, low price for building land intended for social housing. Housing associations have, in effect, no specific legal instruments for acquiring land for social housing below market prices in the Netherlands, but many municipalities assist housing associations through preferential acquisition (pre-emption) or compulsory purchase orders (NEEDHAM and DE KAM, 2000). In Spain, land for social housing is purchased both from local authorities and market players. The municipalities grant subsidies for the purchase of land, especially in areas where the market prices are high. Subsidies are provided by local authorities, who sometimes pay the servicing costs as well (NEEDHAM and DE KAM, 2000). In Spain, autonomous communities and municipalities also designate resources on an annual basis for the promotion of social housing. In addition, since the introduction of regional legislation on urban planning, a minimum of $30 \%$ of each new urban development land parcel must be used for social housing. The minimum percentage is set by the new Bill on State Land, which is currently being debated in Spain's parliament (CECODHAS, 2010, 80/122).

Some countries set the price of land by applying thresholds. For example, in Denmark, the price of land must be below a certain level (14\% to 20\%) of the total costs. However, if the local government sells the land at a price which is lower or higher than the price of 
similar sites, a complaint may be lodged with a higher authority. In Portugal, if the land is connected to infrastructure services, the price is usually fixed at $15 \%$ of the market value of the scheme.

Our results from the online survey confirm that, with the exception of Denmark and Hungary, the land designated for social housing may be sold below the market price in the countries that participated in the survey (Belgium, Ireland, Italy, Poland, France, Finland, Slovenia, the UK and Sweden). In most of these countries, public resources are directly or indirectly geared to keeping the price of land for social housing below the market level.

As experience across Europe shows, the price of serviced land for social housing is a recurrent issue (WLC, 2006; DE KAM et al., 2008; DE KAM, 1998; NEEDHAM and DE KAM, 2000; ICSH, 2006). Some countries (Ireland, Italy and France) are engaged in a debate about whether the regulations are in tune with the Single European Market (violation of the state aid rule), while others are not (Finland, Belgium and Sweden). Our survey shows that in Ireland, despite the absence of stringent regulations, government subsidisation of social housing is substantial (almost $100 \%$ of the construction costs). The Irish Housing Ministry, concerned that this level of support might breach the regulations on state aid, sought guidance from the Commission, (CEC, 2005a) which decided that as social housing in Ireland is strongly targeted at poor households these subsidies do not breach the state aid regulations. Our survey also revealed a debate in Italy, but this has only occurred since 2007 when social housing became an additional social service. The 
debate in France revolves around the role of public land developers (public bodies operating under private law which often take charge of land development in major projects for the local planning authorities). The land developers pursue social objectives, while the provision of land below the market price to allow the realisation of social housing is a widespread practice. Since 2005 the local planning authorities have not been able to freely choose the project developers, as the European rules on procurement demand tendering procedures (ECJ, 2005). This has triggered a debate in policymaking as it is becoming difficult at the local level to continue to provide 'cheap' land for social housing.

\section{Discussion: Do below-market land prices contravene the state aid regulations of the Single European Market?}

The direct or indirect use of government resources to lower land prices for social housing may be considered to be state aid which may be incompatible with the Single European Market. If that is the case, the Commission has an administrative role in the enforcement of European law and has the potential role to intervene in long-established national practices of providing cheap land for social housing, even if such practices are not necessarily distorting cross-border competition. The concept of state aid has become one of the important ways in which the establishment of a Single European Market affects the governance of cities and regions, especially as the ruling neo-liberal governance philosophy has a preference for specific forms of governance in which public and 
private-sector actors cooperate. Single European Market regulations may interfere with localised networks of governance and affect the capacity of local authorities to build networks with market parties in land development (KORTHALS ALTES and TAŞANKOK, 2010). In short, the relations among actors have increasingly become framed by the EU-rules on competition.

Occasionally, the Commission demands answers from member states concerning the infringement of state aid (or European directives in relation to public contracts, for example). This can relate to issues such as urban and regional infrastructure, service provision, or public-private partnerships for urban and regional projects. Europeanisation is a slow process in which questions raised by actors and brought before national (and European) courts play an important role. The result of the conflict in the field of the provision of land for social housing will not be that social housing policies are dismantled by European institutions but that these policies will have to be restructured based on the principles of the Single European Market. Although the European Union has no jurisdiction in housing, it may structure housing policies (ELSINGA et al., 2008). This illustrates the mechanisms by which the Single European Market is organised. The member states have chosen to organise the market based on changing the rules of exchange within it, and not by alternative means, such as changing property rights, governance structures or conceptions of control (FLIGSTEIN and MARA-DRITA, 1996). After all, the provision of cheap land for social housing entails the exchange of goods and the European regulations are concerned with this precisely. However, interfering in the rules of exchange has its impact on other elements that constitute a 
market. Rules of exchange have an impact on resource allocation in the production of social housing provision, which is important when analysing social housing (OXLEY, 1995).

Alongside implications in the field of housing, the European state aid regulations may also have spatial implications. Market prices for land differ between locations and consequently there are spatial differences with respect to the disparity between the price of land for social housing and the price for market housing. Especially in high-priced areas this might lead to substantial land subsidies; potential conflicts are likely to be of greater magnitude in central areas in Europe than in more peripheral areas, especially in areas in which there is a declining population. In central areas, housing affordability is also an issue for 'key workers', such as nurses, teachers, police officers and social workers, for whom 'the lack of development land is a key problem' (MORRISON and MONK, 2006, 1127). In UK, for instance, new spatial policy initiatives have emerged during 2000s to give housing support to key workers with special government programmes (RACO, 2008). The provision of land for affordable housing using state resources may also fall foul of state aid regulations and consequently must be structured by European regulations, which may result in frictions in a context where property markets may already be complex and not very transparent. The impact of state aid policies has, through the housing of key workers, a potentially larger impact on the spatial distribution of housing and patterns of commuting in economically prosperous areas. This issue may relate to other debates in this area, such as value capturing for inclusionary housing (CALAVITA and MALLACH, 2010). 
This spatial impact adds to the impact that state aid regulations may already have on the regeneration of brownfields, where, especially in the UK, state-financing policies had to be restructured after the Commission did not approve the gap-funding system aimed at bridging the financial gap between the costs and benefits of urban regeneration in brownfield areas (ADAIR et al., 2003; KORTHALS ALTES, 2006; VAN CALSTER, 2004).

On the basis of our findings, it should be noted that some specific infringements can be expected in the coming years, given that the price of land for social housing is lowered in one way or another all across Europe. If the social housing system in a country renders tendering procedures undesirable or impossible, the Commission could provide an interpretative framework to make practices that provide land for social housing admissible. In other words, the framework would give guidance to local authorities and specific housing organisations and would clarify the conditions under which these practices accord with the Altmark Judgment. We expect this framework to follow the two lines sketched above. We also expect, however, that in regions where European regional policies are being pursued, there will be a third option under which state aid is provided with the consent of the Commission, which is in turn bound by the Treaties. For example in relation to the 'gap funding' programme for brownfield redevelopment the Commission asked the UK authorities to operate the proposed scheme "as a regional aid scheme in conformity with the relevant State aid rules" (CEC, 2000, 30), i.e. the Guidelines on national negional aid (see also CEC, 2006) and the UK map of assisted 
areas. In this way this brownfield regeneration scheme could be positioned under the provisions of regional State aid. Within areas, which are challenged to operate on the single European Market, state aid, such as for adequate housing for the labour force, may be allowed if it is instrumental in establishing a level playing field.

Meanwhile, debates continue on whether the situation in which some low-income neighbourhoods are located within larger urban areas where the average income is actually higher calls for new policies to improve cohesion in these neighbourhoods and in the single market (CEC, 2008a). This may mean that state aid to improve cohesion in such neighbourhoods might be compatible with single market regulations.

One complicating issue is that inclusive policies, such as the provision of land for social housing in low-income neighbourhoods, may result in strengthening urban segregation of low-income versus high-income urban neighbourhoods. Simply making these areas more attractive to households with more spending power may not be a solution insofar as it may trigger a process of gentrification that could lead to the further concentration of economically challenged households in other neighbourhoods. The answer may therefore lie in providing social housing outside these areas. In other words, giving state aid to undertakings that develop social housing in the more prosperous areas of the EU might be acceptable in the single market under certain conditions since it offers a means of overcoming the lack of cohesion in urban areas. This will require further thought by the Commission and other decision-making bodies in the EU. The green paper on territorial cohesion (CEC, 2008a) states that 'social exclusion ... in deprived urban neighbourhoods 
... [is] associated with the pursuit of territorial cohesion' (CEC, 2008a, 3). The Commission further states that 'high property prices', the 'acute problems of urban decay' and 'social exclusion' (CEC, 2008a, 5) are curbing the economic gains of concentration. According to the Commission, '[t]he focus here should be on reducing the negative externalities of agglomeration and on ensuring that all groups can benefit from highly specialised and productive economies' (CEC, 2008a, 6). Territorial cohesion policies are geared to the perpetuation of the 'European Model of Society' (FALUDI, 2007). The Commission is struggling to find ways to address these issues (FALUDI, 2006) and the green paper is adding to the difficulties by putting specific policy measures on the agenda.

This opens up the debate on the issue. National governments in more prosperous regions may, however, try to keep Europe at arm's length, as they do not expect they will require European funding - which will only push up the EU budget - and because they believe that they can resolve these policy issues themselves. Even so, the policies of the Single European Market are not just about support but about a level playing field where member states can provide state aid themselves.

\section{Acknowledgement}

The authors wish to acknowledge the financial support received from Delft University of Technology via the Delft Centre for Sustainable Urban Areas. We would also like to thank our academic colleagues for cooperating in the survey. 


\section{Appendix 1: Price of land for social housing across Europe and the possibility of state aid regulation problems}

\begin{tabular}{|c|c|c|c|}
\hline & & Price of land & $\begin{array}{l}\text { Below-market prices possibly } \\
\text { problematic for state aid regulations? }\end{array}$ \\
\hline \multirow{7}{*}{ 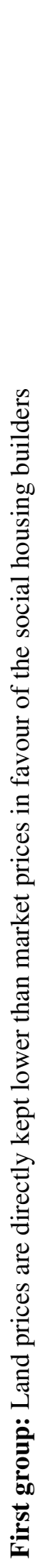 } & Austria & $\begin{array}{l}\text { Below-market } \\
\text { prices/favourably priced }\end{array}$ & Yes, because of the lower land prices. \\
\hline & $\begin{array}{l}\text { Belgium } \\
\text { (Flanders } \\
\text { Region) }\end{array}$ & $\begin{array}{l}\text { The price must not exceed the } \\
\text { market price (assessed by the } \\
\text { Ministry of Finance). }\end{array}$ & $\begin{array}{l}\text { 1) Yes, because it is sometimes difficult to } \\
\text { acquire land at reasonable prices and } \\
\text { Flemish government gives: } \\
\text { a) subsidiary subsidies (to enable social } \\
\text { housing providers to acquire land } \\
\text { irrespective of price fluctuations); } \\
\text { b) loans at reduced interest rates. } \\
\text { 2) A social housing provider can receive a } \\
\text { subsidy to purchase developed land for the } \\
\text { acquisition costs. }\end{array}$ \\
\hline & $\begin{array}{l}\text { Belgium } \\
\text { (Wallonia } \\
\text { region) }\end{array}$ & $\begin{array}{l}\text { Has to be below the market } \\
\text { value estimated by the Comite } \\
\text { d'Acquisition of the Ministry } \\
\text { of Finance. }\end{array}$ & $\begin{array}{l}\text { Yes, because it has to be below the } \\
\text { assessed price. } \\
\text { Yes, because a new regulation introduces } \\
\text { grants for the acquisition of land in certain } \\
\text { locations (former industrial land near } \\
\text { urban centres is soon be developed) by the } \\
\text { regional and provincial government. } \\
\text { Yes, because if the land is highly priced } \\
\text { after servicing it can be sold to the future } \\
\text { owner for a below-market price and the } \\
\text { loss will be covered by the sale of other } \\
\text { land owned by the Societe Wallonne de } \\
\text { Logement. }\end{array}$ \\
\hline & Italy & $\begin{array}{l}\text { The price of land in a PEEP } \\
\text { area is at least } 50 \% \text { lower than } \\
\text { the price of land outside the } \\
\text { area. }\end{array}$ & $\begin{array}{l}\text { Yes, because of the } 50 \% \text { lower land value } \\
\text { in the compulsory purchase. }\end{array}$ \\
\hline & Luxembourg & $\begin{array}{l}\text { The price of the land has to be } \\
\text { low because the sites usually } \\
\text { have no public services and } \\
\text { booming land prices are } \\
\text { making the situation more } \\
\text { difficult. }\end{array}$ & $\begin{array}{l}\text { Yes, because even though the providers } \\
\text { buy the land at market prices, the } \\
\text { government subsidises them to the tune of } \\
40 \% \text {. }\end{array}$ \\
\hline & France & $\begin{array}{l}\text { Checked by a public valuer } \\
\text { (but even if the price is higher } \\
\text { than the valuation the land may } \\
\text { still be acquired for social } \\
\text { housing). }\end{array}$ & $\begin{array}{l}\text { Check out the new law (La loi SRU) } \\
\text { which regulates that the excessive costs of } \\
\text { land are to be fully covered by the national } \\
\text { government. }\end{array}$ \\
\hline & Germany & $\begin{array}{l}\text { Municipality can sell plots for } \\
\text { social housing : } \\
\text { a) at a reduced price } \\
\text { determined by its own costs; } \\
\text { b) at a fixed price agreed by } \\
\text { the city council. } \\
\text { The resulting price is decided } \\
\text { by negotiation, the social } \\
\text { housing provider has no right } \\
\text { to lower land prices. }\end{array}$ & $\begin{array}{l}\text { Yes, because the Bund, the Lander and the } \\
\text { municipalities are required to sell land } \\
\text { from their stock at a reduced price. } \\
\text { Yes, because the municipality grants a } \\
\text { subsidy for the land when the construction } \\
\text { costs are too high. }\end{array}$ \\
\hline
\end{tabular}




\begin{tabular}{|c|c|c|c|}
\hline 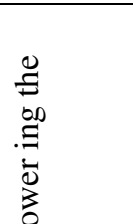 & $\begin{array}{l}\text { The } \\
\text { Netherlands }\end{array}$ & $\begin{array}{l}\text { Building land is made } \\
\text { available to housing } \\
\text { associations at prices much } \\
\text { lower than those paid by } \\
\text { private developers. }\end{array}$ & $\begin{array}{l}\text { Yes, because of the provision of cheap } \\
\text { building land. }\end{array}$ \\
\hline 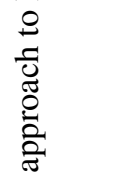 & Norway & $\begin{array}{l}\text { Has to be below a certain norm } \\
\text { in order to obtain loans and } \\
\text { grants from the State Housing } \\
\text { Bank. }\end{array}$ & Yes, because of the lower price norm. \\
\hline$\ddot{\tilde{g}}$ & Spain & Subsidies to lower the prices & Yes, because of the subsidies. \\
\hline 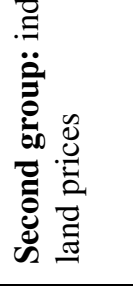 & UK & $\begin{array}{l}\text { Planning agreements to } \\
\text { provide a proportion of the } \\
\text { land or buildings for affordable } \\
\text { housing } \\
\text { Planning obligations and } \\
\text { implicit land taxation }\end{array}$ & Yes, because of the planning obligations. \\
\hline 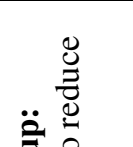 & Denmark & $\begin{array}{l}\text { Has to be below a certain level } \\
\text { ( } 20 \% \text { but usually } 14 \% \text { ) of the } \\
\text { total costs }\end{array}$ & $\begin{array}{l}\text { Yes, if the land price falls far below the } \\
\text { market price after the } 14-20 \% \text { calculation. }\end{array}$ \\
\hline 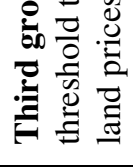 & Portugal & $\begin{array}{l}\text { Usually } 15 \% \text { of the sales value } \\
\text { of the scheme (if the land is } \\
\text { connected to infrastructural } \\
\text { services) }\end{array}$ & $\begin{array}{l}\text { Yes, because of the } 15 \% \text { lower sales value } \\
\text { rule } \\
\text { Yes, because of the dwelling exchange } \\
\text { instead of land purchase. }\end{array}$ \\
\hline & Ireland & $\begin{array}{l}\text { Usually equal to the market } \\
\text { value }\end{array}$ & No \\
\hline 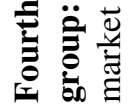 & Sweden & $\begin{array}{l}\text { The municipal company has to } \\
\text { pay market prices. }\end{array}$ & No \\
\hline
\end{tabular}

Source: Compiled by the authors by updating Needham and De Kam, 2000 and CECODHAS (2010) 


\section{Appendix 2: Online questionnaire}

1. Who provides the land for social housing in your country?

a. Public parties only (national, regional and/or local government and other public parties)

b. Private parties only

c. Both public and private parties

If c: Can you explain the way in which both public and private parties are involved?

2. Does it occur in your country that land for social housing is sold below the market price (price for land for private housing)?
a. Yes
b. No

3. Are government/public resources directly or indirectly involved in keeping the price of land for social housing lower than the market price?
a. Yes
b. No

4. Is there any obligation to provide social housing?
a. Yes
b. No

If you wish you can explain your answer here:

5. Are there strict rules about the use of government resources in relation to the obligation to provide social housing?
a. Yes
b. No

If you wish you can explain your answer here:

6. Is there any debate in your country about whether these rules are in conformity with the Single European Market (violation of the state aid regulation)?
a. Yes
b. No

If you wish you can explain your answer here: 


\section{References}

ADAIR A., BERRY J. and MCGREAL S. (2003) Financing property's contribution to regeneration, Urban Studies 40(5-6), 1065-80.

ANDREWS R. and MARTIN S. (2010) Regional Variations in Public Service Outcomes: The Impact of Policy Divergence in England, Scotland, and Wales, Regional Studies 44(8), 919-34.

BENNETT P. (2006) Competing for the Island Lifeline: European Law, State Aid and Regional Public Services, Regional Studies 40(8), 953 - 66.

BRUHNS M. L. (2001) Dienste von allgemeinem wirtschaftlichem Interesse im europäischen Binnenmarktrecht, Ruprecht-Karls-Universität Heidelberg, Heidelberg, http://www.ub.uni-heidelberg.de/archiv/1840/ (date accessed 11/04/2011).

BUITELAAR E., DE DEUGD B. and GEUTING E. (2004) Naar een residueel bepaalde grondprijs voor sociale woningbouw? [Towards a residual based land price for social housing], Tijdschrift voor de Volkshuisvesting 10(6), 56-60.

CALAVITA N. and MALLACH A. (Eds) (2010) Inclusionary Housing in International Perspective: Affordable Housing, Social Inclusion, and Land Value Recapture. Lincoln Institute of Land Policy, Cambridge.

CEC (1997) Commission Communication on State aid elements in sales of land and buildings by public authorities, Official Journal of the European Communities 40(C209), 3-5.

CEC (1999) Invitation to submit comments pursuant to Article 88(2) (ex Article 93(2)) of the EC Treaty, concerning the aid/measure C 11/99 (ex NN 3/99) - the Netherlands - 
Investment aid for Hewlett Packard-SCI Systems, Official Journal of the European Communities 42(C144), 4-8.

CEC (2000) Commission Decision of 22 December 1999 on aid scheme C 39/99 (ex E 2/97) United Kingdom, English Partnerships (EP) under the partnerships investment programme (PIP), hereinafter, 'EP/PIP' scheme, Official Journal of the European Communities 43(L145), 27-35.

CEC (2001) Commission Decision of 13 February 2001 on the State aid implemented by the Netherlands for SCI-Systems, Official Journal of the European Communities 44(L186), 43-57.

CEC (2004) White Paper on services of general interest, COM(2004)374 final, Commission of the European Communities, Brussels, http://eurlex.europa.eu/LexUriServ/site/en/com/2004/com2004_0374en01.pdf (date accessed $11 / 04 / 2011)$

CEC (2005a) Loan Guarantee for social infrastructure schemes funded by the Housing Finance Agency, N 395 / 2005 C(2005)4668 final, Commission of the European Communities, Brussels, http://ec.europa.eu/community_law/state_aids/comp2005/n395-05.pdf (date accessed 11/04/2011).

CEC (2005b) Community framework for State aid in the form of public service compensation Official Journal of the European Union 48(C297), 4-7.

CEC (2006) Guidelines on National Regional Aid for 2007-2013, Official Journal of the European Union 59(C54), 13-44.

CEC (2008a) Green Paper on Territorial Cohesion: Turning territorial diversity into strength, COM(2008) 616 final, Commission of the European Communities, 
Brussels, http://ec.europa.eu/regional_policy/consultation/terco/paper_terco_en.pdf (date accessed 11/04/2011).

CEC (2008b) Commission Regulation (EC) No 800/2008 of 6 August 2008 declaring certain categories of aid compatible with the common market in application of Articles 87 and 88 of the Treaty (General block exemption Regulation), Official Journal of the European Union 51(L214), 3-47.

CECODHAS (2010) Social Housing, website, http://www.cecodhas.org/content/view/12/50/ (date accessed 26/05/2010)

CROOK A. D. H., DUNNING R., FERRARI E. T., HENNEBERRY J. M., WATKINS C. A., BURGESS G., LYALL GRANT F., MONK S., WHITEHEAD C. M. E. and ROWLEY S. (2010) The Incidence, Value and Delivery of Planning Obligations in England in 2007-08, Department for Communities and Local Government, London, http://www.communities.gov.uk/publications/planningandbuilding/planningobligatio nsreport (date accessed 11/04/2011).

DE KAM G. (1998) Value for money: Quality and price of land for social housing in the Netherlands, Journal of Housing and the Built Environment 13(4), 453-75.

DE KAM G., GROETELAERS D. A. and KORTHALS ALTES W. K. (2008) Land for social housing: A framework for cross-national comparative analysis, European Network for Housing Research Conference: Shrinking Cities, Sprawling Suburbs, Changing Countrysides, Dublin (06/07/2008-09/07/2008).

EC (2009a) State aid: Commission approves changes in Dutch social housing system, IP/09/1928, Brussels, 
http://europa.eu/rapid/pressReleasesAction.do?reference=IP/09/1928 (date accessed 11/04/2011).

EC (2009b) Existing and special project aid to housing corporations, E 2/2005 and N 642/2009, C(2009)9963 final, European Commission, Brussels, http://ec.europa.eu/community_law/state_aids/comp-2005/e002-05-en.pdf (date accessed 11/04/2011).

ECJ (1987) Commission of the European Communities v Italian Republic, European Court of Justice, 16/06/1987, C-118/85, http://eurlex.europa.eu/LexUriServ/LexUriServ.do?uri=CELEX:61985J0118:EN:HTML (date accessed 11/04/2011)

ECJ (1991) Klaus Höfner and Fritz Elser v. Macrotron GmbH, European Court of Justice, 23/04/1991, C-41/90, http://eurlex.europa.eu/LexUriServ/LexUriServ.do?uri=CELEX:61990J0041:EN:HTML (date accessed 11/04/2011)

ECJ (2003) Altmark Trans GmbH and Regierungspräsidium Magdeburg v Nahverkehrsgesellschaft Altmark GmbH, European Court of Justice, 24/07/2003, C280/00, http://eurlex.europa.eu/LexUriServ/LexUriServ.do?uri=CELEX:62000J0280:EN:HTML (date accessed 11/04/2011)

ECJ (2005) Commission of the European Communities v French Republic, European Court of Justice, 20/10/2005 C-264/03, http://eurlex.europa.eu/LexUriServ/LexUriServ.do?uri=CELEX:62003J0264:EN:HTML (date accessed 11/04/2011) 
ECJ (2006) Portuguese Republic v. Commission of the European Communities, European Court of Justice, 06/09/2006, C-88/03, http://eurlex.europa.eu/LexUriServ/LexUriServ.do?uri=CELEX:62003J0088:EN:HTML (date accessed 11/04/2011)

ECORYS-KOLPRON (2002) Kosten en kostendragers transformatieopgave stedelijke vernieuwing: Advies in het kader van de commissie "Kosten en kostendragers van transformatie van wijken" onder voorzitterschap van de heer mr. H.E. Koning [Costs and carriers of these costs of the urban regeneration and transformation task; Advice in the context of the committee ... chaired by H.E. Koning], Ministerie VROM, The Hague, http://www.keicentrum.nl/websites/kei/files/stedelijkevernieuwing/artikelen/pubkostenenkostendragersdeel1.pdf (date accessed 18/03/2011).

ECORYS-VASTGOED (2006) De prijs van kwaliteit. Handreiking voor gemeentelijk grondprijsbeleid bij woningbouw, VNG, Neprom, NVB, Ministerie van VROM, Den Haag, http://www.rijksoverheid.nl/bestanden/documenten-enpublicaties/brochures/2006/04/01/de-prijs-van-kwaliteit-handreiking-voorgemeentelijk-grondprijsbeleid-bij-woningbouw/w103.pdf (date accessed 11/04/2011). EEC (1957) Treaty Establishing the European Economic Community, Rome, http://eurlex.europa.eu/en/treaties/ (date accessed 11/04/2011).

ELSINGA M., HAFFNER M. and HEIJDEN H. V. D. (2008) Threats to the Dutch unitary rental market, European Journal of Housing Policy 8(1), 21-37.

EU (2010) Consolidated Version of the Treaty on the Functioning of the European Union, Official Journal of the European Union 53(C83), 47-200. 
FALUDI A. (2006) From European spatial development to territorial cohesion policy, Regional Studies 40(6), 667-78.

FALUDI A. (2007) Territorial cohesion policy and the European model of society, European Planning Studies 15(4), 567-83.

FLIGSTEIN N. and MARA-DRITA I. (1996) How to Make a Market: Reflections on the Attempt to Create a Single Market in the European Union, American Journal of Sociology 102(1), 1-33.

GROETELAERS D. and KORTHALS ALTES W. K. (2004) Policy Instruments in the Changing Context of Dutch Land Development, in DEAKIN D., DIXON-GOUGH R. W. and MANSBERGER R. (Eds) Methodologies, Models and Instruments for Rural and Urban Land Management, pp. 75-87. Ashgate, Aldershot.

GRUIS V. and PRIEMUS H. (2008) European competition policy and national housing policies: International implications of the Dutch case, Housing Studies 23(3), 485505.

ICSH (2006) Survey findings on acquisition of land for social housing in the voluntary housing sector 2000-2004, Irish Council for Social Housing, Dublin, http://www.icsh.ie/eng/services/publications/icsh_publications (date accessed 26/05/2010).

KORTHALS ALTES W. K. (2006) The single European market and land development, Planning Theory and Practice 7(3), 247-66.

KORTHALS ALTES W. K. (2010) Europeanization as Discontinuous Adjustment: A Düsseldorf Court's Impact on Land Development Practice, European Planning Studies 18(5), 811-28. 
KORTHALS ALTES W. K. and TAŞAN-KOK T. (2010) The Impact of European Public Contract Law on Networks of Governance: A Relational Approach, European Planning Studies 18(6), 967-84.

KROES N. (2009) Antitrust and State Aid Control - The Lessons Learned, in HAWK B. E. (Ed) 36th Annual Conference on International Antitrust Law and Policy, Fordham University, New York. http://www.europa-eu-un.org/articles/en/article_9019_en.htm (date accessed 19/10/2010)

LOUIS F. and VALLERY A. (2004) Ferring revisited: the Altmark case and state financing of public service obligations, World Competition 27(1), 53-74.

MORI H. (1998) Land Conversion at the Urban Fringe: A Comparative Study of Japan, Britain and the Netherlands, Urban Studies 35(9), 1541-58.

MORRISON N. and MONK S. (2006) Job-housing mismatch: Affordability crisis in Surrey, South East England, Environment and Planning A 38(6), 1115-30.

NEEDHAM B. (1992) A Theory of Land Prices when Land is Supplied Publicly: The Case of the Netherlands, Urban Studies 29(5), 669-86.

NEEDHAM B. and DE KAM G. (2000) Land for social housing, in co-operation with CECODHAS, Nijmegen/Hilversum, http://www.ru.nl/aspx/download.aspx?File=/contents/pages/140643/landforsocialhous ing.pdf (date accessed 22/03/2011).

NEEDHAM B. and DE KAM G. (2004) Understanding How Land is Exchanged: Coordination Mechanisms and Transaction Costs, Urban Studies 41(10), 2061-76. 
OXLEY M. (1995) Private and social rented housing in Europe: Distinctions, comparisons and resource allocation, Scandinavian Housing and Planning Research 12(2), 59-72.

OXLEY M. (2008) Implicit land taxation and affordable housing provision in England, Housing Studies 23(4), 661-71.

PRIEMUS H. (2006) European policy and national housing systems, Journal of Housing and the Built Environment 21(3), 271-80.

PRIEMUS H. (2008) Real estate investors and housing associations: A level playing field? the Dutch case, European Journal of Housing Policy 8(1), 81-96.

RACO M. (2008) Key Worker Housing, Welfare Reform and the New Spatial Policy in England, Regional Studies 42(5), 737-51.

SMALLBONE D., CUMBERS A., SYRETT S. and LEIGH R. (1999) The single European market and SMEs: A comparison of its effects in the food and clothing sectors in the UK and Portugal, Regional Studies 33(1), 51-62.

SMITH M. P. (1998) Autonomy by the Rules: The European Commission and the Development of State Aid Policy, Journal of Common Market Studies 36(1), 55-78.

UNECE (2006) Guidelines on social housing: Principles and examples, United Nations Economic Commission for Europe, New York and Geneva, http://www.unece.org/hlm/documents/Publications/guidelines.social.housing.pdf (date accessed 26/05/2010).

VAN CALSTER G. (2004) Will the EC get a finger in each pie? EC law and policy developments in soil protection and brownfields redevelopment, Journal of Environmental Law 16(1), 3-18. 
VAN DER HEIJDEN H., GROETELAERS D. and DE VRIES P. (2006) Wegwijs in de grondprijs: (on)mogelijkheden om gronduitgifteprijzen voor woningbouw te monitoren, Onderzoeksinstituut OTB, TU Delft, Delft, http://repository.tudelft.nl/view/ir/uuid:4dc1ea2f-6486-48e5-9df0-71705f27f491/ (date accessed 21/10/2010).

VAN DIJK T., MUÑOZ-GIELEN D. and GROETELAERS D. (2007) Expanding cities: A grounded conceptual model that allows comparing systems of greenfield land development, Town Planning Review 78(3), 279-310.

WHITEHEAD C. and SCANLON K. (Eds) (2007) Social Housing in Europe. London School of Economics and Political Science, London.

WLC (2006) Affordable housing policy, West Lothian Council, Livingston, http://www.westlothian.gov.uk/media/downloaddoc/1799514/1841832/1850797/1874 545/affordablehousing (date accessed 26/05/2010). 


\section{Figure 1: Setting a price for the supply of municipal land}

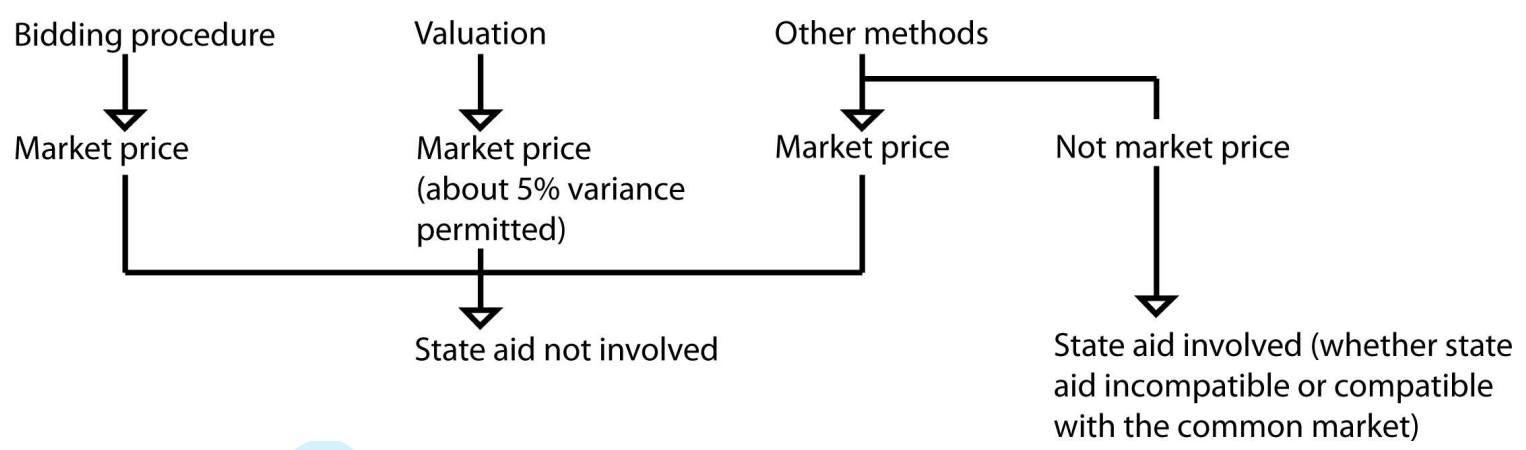


Figure 2: Residual calculation and the distribution of residual or windfall values

2

3

4

5

6

7

8

9

10

11

12

13

14

15

16

17

18

19

20

21

22

23

24

25

26

27

28

29

30

31

32

33

34

35

36

37

38

39

40

41

42

43

44

45

46

47

48

49

50

51

52

53

54

55

56

57

58

59

60

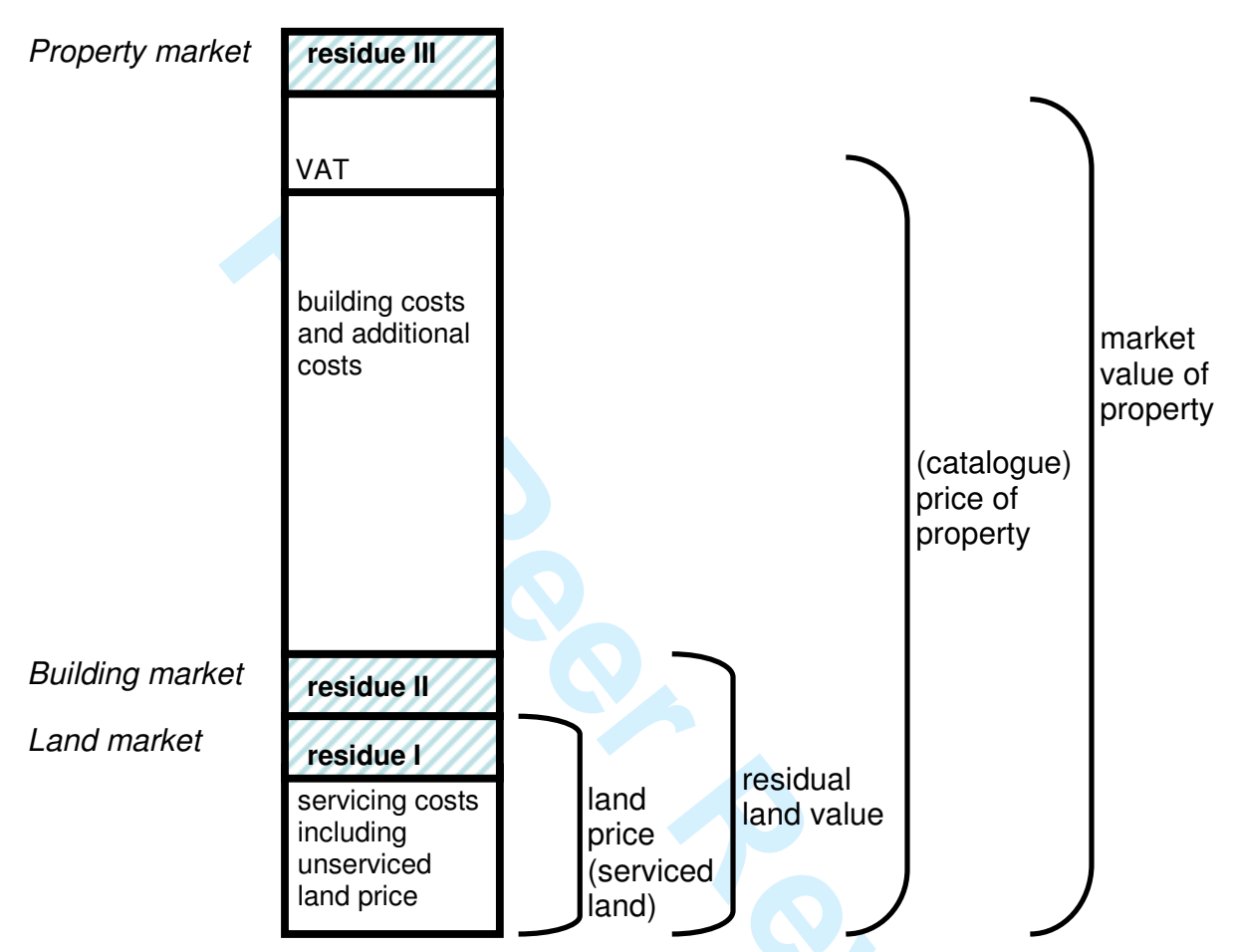

